\title{
Correction to: Framing natural assets for advancing sustainability research: translating different perspectives into actions
}

\author{
Maria Jose Martinez-Harms ${ }^{1,2}$ (D) Stefan Gelcich ${ }^{1} \cdot$ Rainer M. Krug $^{3} \cdot$ Fleur J. F. Maseyk ${ }^{2,4} \cdot$ Hannah Moersberger $^{5}$. \\ Archi Rastogi $i^{6}$. Geoffrey Wambugu ${ }^{7}$. Cornelia B. Krug ${ }^{8,12}$. Eva M. Spehn ${ }^{9}$. Unai Pascuall ${ }^{10,11,13}$
}

Published online: 24 December 2020

(c) The Author(s) 2020

\section{Correction to: Sustainability Science (2018) 13:1519-1531 https://doi.org/10.1007/s11625-018-0599-5}

In the original publication of the article, under the acknowledgments section, the project number was published incorrectly. The correct sentence should read as "MMH is supported by Fondo Nacional de Desarrollo Científico y Tecnológico FONDECYT 3180118”.

Open Access This article is licensed under a Creative Commons Attribution 4.0 International License, which permits use, sharing, adaptation, distribution and reproduction in any medium or format, as long as you give appropriate credit to the original author(s) and the source, provide a link to the Creative Commons licence, and indicate if changes were made. The images or other third party material in this article are included in the article's Creative Commons licence, unless indicated otherwise in a credit line to the material. If material is not included in the article's Creative Commons licence and your intended use is not permitted by statutory regulation or exceeds the permitted use, you will need to obtain permission directly from the copyright holder. To view a copy of this licence, visit http://creativecommons.org/licenses/by/4.0/.

Publisher's Note Springer Nature remains neutral with regard to jurisdictional claims in published maps and institutional affiliations.

The original article can be found online at https://doi.org/10.1007/ s11625-018-0599-5.

Maria Jose Martinez-Harms

mariajosesmart@gmail.com

1 Center for Applied Ecology and Sustainability (CAPES), Center for the Study of Multiple-Drivers On Marine Socio-Ecological Systems, Pontificia Universidad Catolica de Chile, Avd. Libertador Bernardo O'Higgins 340, Santiago, Chile

2 Australian Research Council Centre of Excellence for Environmental Decisions, School of Biological Sciences, The University of Queensland, Saint Lucia, QLD 4072, Australia

3 Department of Evolutionary Biology and Environmental Studies, University of Zurich, Winterthurerstrasse 190, 8057 Zurich, Switzerland

4 The Catalyst Group, PO Box 362, Palmerston North 4440, New Zealand

5 Future Earth Paris Hub, Centre National de La Recherche Scientifique (CNRS), 4 Place Jussieu, 75005 Paris, France

6 Universalia Management Group, 245 Victoria Avenue, Suite 200, Westmount, QC, Canada
7 School of Natural Resources and Environmental Studies, Karatina University, PO Box, Karatina 1957-10101, Kenya

8 URPP Global Change and Biodiversity, University of Zurich, Winterthurerstrasse 190, 8057 Zurich, Switzerland

9 Global Mountain Biodiversity Assessment, Institute of Plant Sciences, University of Bern, Altenbergrain 21, 3013 Bern, Switzerland

10 Basque Centre for Climate Change, University of the Basque Country (UPV-EHU), Sede Building 1, 1st Floor, Scientific Campus, Leioa, 48940 Bilbao, Spain

11 Ikerbasque, Basque Foundation for Science, María Díaz Haro, 3, 48013 Bilbao, Spain

12 bioDISCOVERY, Department of Geography, University of Zurich, Winterthurerstrasse 190, 8057 Zurich, Switzerland

13 Centre forDevelopment and Environment, University of Bern, Mittelstrasse 43, 3012 Bern, Switzerland 